\title{
The Performance of School Principals in The Implementation of School-Based Management In State Vocational School (SMKN) 1 of Al Mubarkeya and SMK Negeri 1 of Darul Kamal Aceh Besar Regency
}

\author{
Suci Fajar Rizky, Murniati Ar, Nasir Usman \\ Program Studi Magister Administrasi Pendidikan, Program Pascasarjana, Universitas Syiah \\ Kuala \\ \{Uci9194@gmail.com\}
}

\begin{abstract}
The implementation of a School-Based Management in a school might be correlated to the performance of the school principal. The aim of this research was to identify the leadership, motivation, discipline, and commitment of the school principals in implementing the School-Based Management (SBM) in State Vocational School (SMKN) 1 Al Mubarkeya and State Vocational School (SMKN) 1 of Darul Kamal, Aceh Besar Regency. A descriptive research method and a qualitative research approach were used in this study. The data were collected by doing interviews, doing observations, and collecting other relevant facts or physical evidence. The principals, the vice principals, the teachers, and the educators or staffs in the schools were the subjects of this research. The results indicate that: (1) the leadership of the principals had a crucial role in implementing SBM since the principals were the ones who made a decision or planning regarding the eight teams who would work on the eight national education standards. It was also found that (2) the motivation was expected to be shown not only from the principal but also from the teachers or the educators. In addition, (3) the discipline of all of the schools' elements was affected by the discipline shown by the principal. Finally, (4) the commitment of the principals in implementing the SBM was in accordance with the planning that had been made.
\end{abstract}

Keywords: Performance, Principal, School-Based Management

\section{Introduction}

An awareness toward the importance of the educational quality which can provide hope and having the possibility to get a better future has encouraged various efforts and attention of all levels of society. They pay attention to every movement and development in the educational world. Education is one of the efforts to improve the quality of human life which aims to humanize humans, to mature, to change behavior, and to improve quality for the better.

Nowadays, the quality of education in Indonesia, especially in Aceh, still has frequent improvements and various efforts have been made to improve the quality of education. Consequently, the government's effort to achieve good quality in the educational world is to implement the national standards of education. 
According to the Government Regulation [1] on National Standards of Education in Chapter XV Article 91 on the 1st Paragraph states that: "Setiap satuan pendidikan pada jalur formal dan nonformal wajib melakukan penjaminan mutu pendidikan." In essence, education includes educating, teaching and training activities. The activity is carried out as an effort to transform values. These transformed values include cultural values, knowledge values, and technology. Then, these values are transformed to maintain, to develop, and to change the culture that belongs to the community. Hence, National Education System formulates that national education aims to develop the potential students to become human beings who have faith in God, have a noble character, healthy, knowledgeable, capability, creativity, independent, become democratic and being responsible citizens.

In fact, education is not solely an easy effort, but it takes a dynamic and challenging activity. Education will always change as time goes by. Consciously, education always becomes the vocal point and even becomes the target of dissatisfaction because education belongs to every people. It is not only related to investment or living conditions in the future, but it also has an influence on life currently. Therefore, education alwaysrequires effort and improvement along with the increasing of peoples' needs and demands.

As an educational institution, a school is a place for educational activities which certainly has an integrated and dynamic system. At present, school is not only a place for teachersstudents interaction, but it is interrelated systems. Moreover, it is seen as an organization that requires management in order to produce the quality of educational institutions. The main activity of the school is the management of the human resource. In optimizing the management of human resources, a good system and management are needed in the implementation of the educational process in school. Management is a function related to efforts to achieve the goal. Indeed, it means that human resources have an important role in achieving goals, especially the educational goals that have been formulated in an institution.

How the peoples do in a real workplace becomes the measuring rod to see the quality of the education. It concerns of how the capability related to the skills upon the working demands, how the school graduation toward the alumnus and the qualifications of jobs' opportunities, and how the alumnus from the educational institutions getting involved in the workplace. In short, one of the measuring rod upon the quality of education in an educational institution is the ability of the educational institution to produce the quality of human resources.

To resolve the various problems of education in Indonesia, the government has carried out various innovations in the educational fields, such as education autonomy policies, school-based management, ratifying the regulation of national education system, establishing national standards of education, and socializing the implementation of the latest curriculum. In addition, the improvement of teachers' professionalism quality through certification and competency tests are also carried out. Furthermore, the strategic plans toward educational innovations have also been carried out with the ultimate goal of improving the quality of education.

Actually, vocational education becomes the government's efforts in improving the quality of education relating to the work world. According to Regulation No. 20 Tahun 2003 [2] concerning the National Education System stated that vocational education is education that prepares students to have an ability to work in certain fields. Murniati [3] argues that "vocational education is education that provides students to have various knowledge, skills, and experiences so that they are able to do certain jobs for themselves, for the work world, and for the development of their nation".

The vocational education has the relation to the industrial process, especially to fulfill the human resource demands. It is such a challenging work to do since the vocational schools have a responsibility to prepare the skillful human resources. Yet, only a few vocational schools that 
are able to implement the educational program in enhancing students to be knowledgeable, skillful, having experienced so they have the capability in doing a certain job.

The important task of the school principal is to achieve the objectives of vocational schools in preparing skilled alumnus as expected. This expectation is certainly inseparable from the performance of a school principal in performing an educational institution based on the standards of national education.

Fortunately, vocational school is one of the educational institutions that have a considerable impact on the implementation of SBM. The challenges faced by vocational management are changes in various types of work fields and qualifications. In fact, the challenge is quite hard. Some technology experts argue that the education of ready-to-use labor is an unrealistic concept because the development of technology is fast. Then, it is impossible to be followed by a vocational school. The practice facilities at vocational schools will be lag behind. In another idea is stated by economists that the implementation of vocational schools is too expensive compared to the rate of return. Then, this thing must take into account.

The implementation of SBM requires the professional leadership of school principals that has management ability and personal integrity that put the vision into action, being democratic, and transparent in decision making. In implementing SBM, school principals are the key success in improving the quality of education in schools. Therefore, the principal must have a vision, mission, and broad insights about effective schools in implementing SBM. In addition, professional skills are required in realizing it through the performance of the school principal.

\section{Result And Discussion}

\subsection{Performance Theory}

Performance is related to the achievement level toward the implementation of a program/activity/policy in realizing the goals, objectives, vision, and mission of the school. Usman[4] revealed that "Performance is an action that is performed through the skills and motivation shown by each employee, both in quality and quantity in carrying out their work in accordance with the responsibilities." Furthermore, according to Fahmi[5], "Performance is the result obtained by an organization which is profit oriented and non- oriented produced over a period of time." Indeed, the basic principle is a description of the achievement level of an activity or program in realizing goals, objectives, mission, and vision contained in the strategic schemes.

Good performance can be influenced by capability and motivation. Performance is an achievement that can be achieved by a person or organization based on certain criteria and instruments. According to Drucker in Usman [4], "the parameter that is commonly used is effectiveness, efficiency, and productivity." Furthermore, Armstrong and Baron in Fahmi[5] revealed that: "Performance is the result of work that has a firm relationship with the goal of the organization, customer satisfaction, and giving the economic contribution." In an organization or society, individuals contribute their performance to the group. Then, the group will contribute its performance to the organization or society. In an effective organization, management always creates positive synergies, which yield a greater result.

\subsection{School Principal}

According to Karwati \& Priansa [6] "School principal is the responsibility to lead a school, where the instructional process is held including the teachers-students interaction." In another 
definition, the principal is those who know a lot of their duties and those who determine the needs of their school.

The principal's performance is the effort that can be achieved by the principal in implementing the school management both in quality and quantity to achieve the educational goals effectively, efficiently, productively, and accountably. The performance of the principal is the result of implementing work in physical/material and non-physical/non-material in a certain period of time.

Based on Permendiknas of 2007 [7], [8] concerning the standards of school principal determined that principals are required to master the dimensions of personal, management, entrepreneurial, supervisory and social competence. In fact, most school principals do not master the standards of competency required. Due to this reality, the quality of educational institutions will not be achieved properly. The successful educational institutions are largely determined by the principal as a top manager.

Regulation of the Minister of National Education Permendiknas of the Indonesian Republic No 28 of 2010 [9] concerning the assignment of teachers as principals provides fresh air for increasing the professionalism of a school principal. In the Permendiknas, it is explained that a teacher who had passed the selection of prospective school principals was required to attend education and training as an activity to provide theoretical and practical learning experiences aimed at developing knowledge, attitudes, and skills in the dimensions of personality, management, entrepreneurship, supervision, and social competence.

\subsection{School-Based Management}

School-Based Management, first appeared in the United States. The background begins with the curiosity of the community about what schools can offer to the community. It is also the relation between education and the community needs. At that time, the community thought that school performance was not able to prepare the students in entering the business worlds. They also thought that the school is not able to provide the results in the context of competitive economic life.

School-based management is a new paradigm of education that provides school to be independent within the framework of national education. In another term, the school has broad autonomy. Autonomy is given so that schools are free to manage the resources and funds by allocating them according to the needs or local needs.

Based on the terminology, school-based management comes from three words, namely management, basic, and school. Management is the process of using resources effectively to reach the target. Then, based which means basic or principle, while the school is learning and teaching institution and a place to receive and give lessons. Conceptually, school-based management is as an alternative choice to managing the structures of education by placing schools as the main unit of improvement. The authority of policymakers is as a basic element in this concept to improve the quality of educational outcomes. On the other hand, school-based management is a way to motivate school principals to be responsible for the quality of students.

For this reason, principals should develop comprehensive educational programs to serve all the needs of students in schools. All school personnel should take part in formulating an operational program because they have an awareness about the needs of their students. Hence, school-based management is a strategy to improve education by transferring important decisions by the state and local government to the individuals in a school. Additionally, school-based management provides principals, teachers, students, and parents with enormous control in the educational process by giving them full authority and responsibility to independently determine 
educational programs including curriculum and its implications for various school policies in accordance with the vision, mission and objectives of the education.

Starting from the conditions and restructuring of school management, in the context of the educational development in Indonesia, a school system is needed to provide basic capabilities for students. The concept of school-based management upon the students' improvements is defined as a form of educational reform. It is directed at designing and modifying the structure of government into a school with the concept of school empowerment.

The focus of empowerment is intended to increase the autonomy and professionalism of schools which becomes the quality of education. The school management idea should need to be well understood by all stakeholders in the implementation of education, especially schools because school-based management does not merely bring basic changes in terms of policies and orientation, but it takes part in parental and community participation.

During this time, educational management was embraced and centralistic implemented, where the department center is very dominant in decision making. In contrast, regions and schools are passive because they were only as recipients and implementers of central policies. Centralistic education systems often yielded a gap between school needs and central policy. Therefore, school-based management provides more autonomy to schools. Fortunately, schools have greater authority and responsibility in managing their schools so that they are more independent. Then, schools are more empowered in developing programs that are certainly more in line with their needs and abilities/potential. Due to a sense of belonging, it will lead to an increased sense of responsibility. Increased accountability will increase the dedication of every stakeholder in the school. This is the goal of the school and community participation in education. Through SBM, effective schools can be developed independently because schools are given greater authority and responsibility (autonomy) to manage their potential resources, both human resources and other resources (money, equipment, materials, time and so on). Moreover, school management will occur and expected to support the implementation of an effective and efficient in the teaching and learning process that will improve the quality of education. Indeed, SBM is one of educational reform that offers schools to provide a better and more adequate education for students.

School-Based Management is an alternative form of school as a result of the decentralization of education. The principle of SBM relies on schools and society. After that, SBM has the potential to increase community participation, equity, efficiency, and management that relies on schools or madrasah. SBM is intended to increase school autonomy, determine what teaching needs and manage existing resources to innovate. SBM also has the potential to improve and create school principals, teachers, and administrators to be professional, and the needs of each student and the school community. Student achievement can be optimized through the direct participation of parents and the community. Undoubtedly, increasing the quality of education is not an easy task because it is not only related to technical problems, but it also covers a variety of very complex problems, either concerning planning, funding, efficiency or effectiveness in the school system. Then, improving the quality of education also demands better management of education.

According to Mulyasa[10] "school-based management is one of educational reform that offers schools to provide a better and more adequate education for students." Similarly, schoolbased management is a strategy to improve schools by giving authority to school. Even, schoolbased management gives great freedom and power to the school accompanied by a set of responsibilities. The responsibility for resource management and the development of schoolbased management strategies run in accordance with local conditions, so the schools can further improve the teachers' welfare so they can concentrate more on their tasks. 
The application of SBM in the school refers to the Regulation of National Education Permendiknas No. 19 of 2007[8] concerning to the Standards of Educational Management by the Primary and Secondary Educational Unit [11]. The main feature of School-Based Management is the independence of the school in all aspects to determine the direction of development. Then, it is adapted based on the conditions and the demands of the local community.

Furthermore, The World Bank [11] said that: "School-Based Management is decentralized level of school administration authority to the school level." Hence, the school principal has a responsibility in decision-making on school implementation. Even, teachers, parents, students and other members of the school community.

In Aceh, every level of education has implemented a School-Based Management system which has been approved by the local government in accordance with Aceh Law or Qanun No.5 of 2008[12] "Management of formal education at the elementary and secondary education level implements School-Based Management (SBM) in accordance with religious, social and cultural values." So that, every school in Aceh implements School-Based Management.

\subsection{Characteristic of School-Based Management}

School-based management has characteristics that need to be understood by schools. In other words, if the school wants to be successful in implementing school-based management, the following characteristics of SBM need to be owned. The characteristics of SBM cannot be separated from the characteristics of an effective school. In another word, SBM is a container or framework, then the effective school is the contents.

The characteristics of SBM consist of effective school elements, which are categorized into input, process, and output. The characteristic of SBM based on the aspect of educational input are having clear policies, objectives, quality and having the available resources, highly competent and dedicated staff, and having high achievement expectations, focusing on students and management input.

Effective schools generally have a characteristic process, namely a learning process that is more effective, the firm school leadership, a safe and orderly school environment, an effective management of educational staff, having a quality culture, having an intelligent and dynamic timework, independent, having high participation from school members and the community, transparency of management. It is also including the schools that carry out continuous evaluation and improvement and the schools that are responsive and perceptive toward the needs and have accountability.

According to Brown in Yahya[13], the main and effective characteristics in implementing SBM in schools are as follows.

a) School autonomy

Autonomy is defined as the authority or independence which is independence in managing and not depending on the others. Independence in funding programs is the main benchmark for an independent school. Independency that takes place continuously will guarantee the development of the school.

b) Flexibility.

Flexibility can be interpreted as the free authority given to schools to manage, to utilize and to empower the schools' resources as optimally as possible to improve schools. Indeed, the schools will be more agile and do not have to wait for the direction from their superiors in managing, utilizing and empowering their resources. In this way, the school will be more responsive and faster in responding to all challenges faced. 
However, the flexibility must remain within the corridor of existing policies and regulations.

c) Cooperation

SBM that is able to improve the quality of education demands the cooperation between the stakeholders in the school. The impact will be beneficial for the students, especially the importance of teamwork in the learning process.

d) Participation

Participatory improvement aimed to create an open and democratic environment. The stakeholder in a school (teachers, students, staffs, and the community are encouraged to be directly involved in conducting education starting from the decision making, implementation, and evaluation of education that is expected to improve the quality of education.

Additionally, apart from the characteristics of school-based management, there are several facts that need to be considered toward school-based management that relate to (1) school obligations, (2) government policies and priorities, (3) the role of parents and society, (4) the role of professionalism, management, and professional development.

a) School Obligations

Schools are required to be able to display transparency, democratic, without a monopoly, and having responsibility for the community and the government in order to increase the service capacity for students. Therefore, the implementation needs to be accompanied by a set of obligations, monitoring and relatively high demands of accountability. Afterward, schools which have autonomy also have an obligation to implement government policies and meet the expectations of the school community.

b) Government Policies and Priorities

Since the government has the responsibility for national education. They have the right to formulate policies that become national priorities, especially those in which is related to literacy and numeracy programs, efficiency, quality, and education equity.

c) The Role of Parents and Communities

In implementing SBM, the active involvement of various community groups and parents in the planning, organizing and monitoring educational programs in schools is something that is utmost importance to consider. The community and parents must be aware that education is our responsibility. Then, the school is an educational institution that needs to be supported by all parties.

d) Role of Professionalism and Management

School principals, teachers, and administrative personnel must have to be professional and have management characteristics in order to meet the requirements for SBM implementation. School principals are demanded to study more about government policies and priorities, especially their school priorities.

e) Professional Development

In SBM, the government must ensure that all important elements of education staff (human resources) receive the professional development needed to manage schools effectively. In addition, it is important to note that schools and communities should be involved in the process of implementing SBM as early as possible.

Thus, the application of school-based management is commonly known among others. Then, the schools can optimize school organization, learning processes, human resource management, management of resources and administration. 
Based on implementation studies in other countries, it is also expressed and implied in government policies and the National Education System Law No. of 2003 concerning community-based education in article 55 on 1st paragraph: the community has the right to organize community-based education in formal and non-formal education in accordance with the religion, social environment, and culture for the benefit of the community. Similarly, there are at least four aspects in it namely quality, relevance, justice, effectiveness and efficiency, and accountability.

SBM aims to achieve the highest quality and relevance of education. It is in accordance with a benchmark of outputs and outcomes assessment rather than on the methodology or process. In another idea, the results of educational quality are at the same time relevant to various needs and contexts. If we separate them, then, the quality refers to achieving specific goals by students (graduates), such as test scores or other achievements. While the relevance refers more to the benefits of what students get through education in various fields/life demands and including education that is not tested.

SBM aims to ensure justice for every child to obtain the quality of education in the school. Since every child has the potential to learn, SBM has the flexibility for each school to handle every child with a different socio-economic and psychological background. It makes them have the opportunities to get a better education so they can grow optimally. Then, every school must serve every child, and the school must achieve minimum competency standards for each graduated child. This justice is so important so that effective school experts shorten the objectives of effective schools only on quality and justice.

SBM aims to improve effectiveness and efficiency. Effectiveness relates to the process, procedure, and the use of all inputs used in the education process in the schools, so it produces students' learning outcomes as expected. To know how the school is effective or not, then the result will be determined after the evaluation assessed. On the contrary, to achieve good results, every effort is made to apply the indicators or characteristics of effective schools. By applying SBM, it is expected that every school, according to the conditions can apply the right method. Then, other inputs are put in the right way so that all inputs are effective and targetted. In other words, it is effective to improve the quality of education. Meanwhile, the term of efficiency relates to the value of money spent to fulfill all inputs.

SBM aims to increase school accountability and commitment of all stakeholders. Accountability is the responsibility for everything that is done in accordance with the authority and responsibility obtained. Recently, school accountability is more about financial administrative problems and in accordance with the bureaucratic path. The technical responsibility is limited to the implementation of the program according to instructions and guidelines from the central department without accountability toward the results of the implemented program. Through SBM, schools can improve their capabilities in planning, managing, financing, and organizing the educational program in the school. Then, schools can also utilize and empower available resources and can increase the awareness of the school member and community members in the implementation of education in accordance with their abilities.

School-based management focuses on aspects of school independence with the transparency characteristics of implementation that starts from planning until reporting. Autonomy can create independence with the direct involvement of the school and the community toward the formulation of school programs. The flexibility in managing the resources and community participation to participate, having the professional school principal in carrying out his role as a manager and as a leader. It also gives opportunities for school principals to compile curriculum 
and teachers can innovate by developing curriculum in accordance with the conditions and needs of the school.

School-based management encourages the professionalism of teachers and principals as school managers. School-based management emphasizes the maximum involvement of various parties such as the participation of staff, teachers, parents, students, and the wider community in the formulations of school decisions. Participation can increase their commitment to the school. Furthermore, it supports effectiveness in achieving school goals. The society provides control and monitoring from the government so that school management becomes accountable, transparent, egalitarian, democratic, and eliminates monopoly practices in school management. Finally, SBM makes community involvement in decision making, formulating school programs, and formulating costs, and sources of funds. School decisions are no longer only from school principals but decision making takes part from community schools.

\section{Conclusion}

The principal's performance is the performance performed by the principal through skills and motivation, both in quality and quantity, she is carrying out his/her work in accordance with the responsibilities required. The principal has a role in the implementation of SBM where a school principal must be able to make decisions and conduct planning at the beginning of the year by forming 8 teams to organize the planning of 8 the standard of national education. The motivation of principals in carrying out SBM is done not only for principals but also for educators and education. The principal's discipline affects the performance of all school because the principal is a role model for the school community.

\section{REFERENCES}

[1] Peraturan Pemerintah Republik Indonesia Nomor 19 Tahun 2005, Standar nasional pendidikan. 2005.

[2] Undang-Undang Republik Indonesia Nomor 20 Tahun 2003, Sistem pendidikan nasional. Republik Indonesia, 2003.

[3] A. R. Murniati, Manajemen stratejik peran kepala sekolah dalam pemberdayaan. Bandung: Citapustaka Media Perintis, 2009.

[4] H. Usman, Manajemen teori, praktik, dan riset manajemen teori, praktik, dan riset pendidikan. Jakarta: Bumi Aksara, 2013.

[5] I. Fahmi, Manajemen kinerja. Bandung: Alfabeta, 2013.

[6] E. Karwati and D. J. Priansa, Kinerja dan profesionalisme kepala sekolah. Bandung: Alfabeta, 2013.

[7] Republik Indonesia, Peraturan menteri pendidikan nasional republik indonesia nomor 13 tahun 2007 tentang standar kepala sekolah/madrasah. 2007.

[8] Republik Indonesia, Peraturan menteri pendidikan nasional republik indonesia nomor 19 tahun 2007 tentang standar pengelolaan pendidikan oleh satuan pendidikan dasar dan menengah. 2007.

[9] Republik Indonesia, Peraturan menteri pendidikan nasional nomor 28 tahun 2010 tentang penugasan guru sebagai kepala sekolah/madrasah. 2010.

[10] E. Mulyasa, Manajemen berbasis sekolah. Bandung: Remaja Rosdakarya, 2014.

[11] Suparlan, Manajemen berbasis sekolah. Jakarta: Bumi Aksara, 2013.

[12] Gubernur Nanggroe Aceh Darussalam, Qanun aceh nomor 5 tahun 2008 tentang penyelenggara pendidikan. 2008. 
[13] A. M. Yahya, "Strategi kepala sekolah dalam mengimplementasikan manajemen berbasis sekolah di smp negeri 2 tombolo pao kec. tombolo pao kab. gowa," Universitas Islam Negeri Alauddin, 2014. 